\title{
Identification of soil factors that relate to plant parasitic nematode communities on tomato and yam in the French West Indies
}

\author{
Patrice Cadet ${ }^{\mathrm{a}, *}$, Jean Thioulouse ${ }^{\mathrm{b}, 1}$ \\ a ORSTOM, BP 8006 Fort-de-France, Martinique \\ b CNRS UMR 5558 and ORSTOM, BP 1386 Dakar, Senegal \\ Received 11 June 1997; accepted 7 November 1997
}

\begin{abstract}
A soil and nematode survey of tomato and yam crops was made in Martinique (French West Indies). Each sample was divided into two parts, one for the nematode study and one for the soil analysis. The coupling of the data was made using the coinertia analysis. For tomato plants which were grown from seeds, the nematode-soil relationships were very strong. For the two varieties of yams, Dioscorea cayenensis-rotundata and D. alata, whose infested seed tubers carry nematodes into the field, the relationships were weaker and depended on the yam variety. For D. cayenensis-rotundata, which was attacked by the endemic parasite Pratylenchus coffeae, the relationship between nematode community and soil type was strong. For D. alata, this relationship was weaker because it is mainly parasitised by the exotic species, Scutellonema bradys, which is exclusively introduced into the field with the seed tuber, whatever the soil type. Soil texture was the most important factor explaining the presence of some species. However, Meloidogyne spp. and the ectoparasitic species such as Xiphinema spp. were associated with light andosols; Aorolaimus luci needed, in addition, higher levels of organic matter. P. coffeae preferred any type of soil rich in organic matter and its abundance seemed influenced by calcium and magnesium content or $\mathrm{pH}$. In contrast, $P$. brachyurus did not appear to be sensitive to any of the measured physico-chemical soil characteristics. (C) 1998 Published by Elsevier Science B.V. All rights reserved.
\end{abstract}

Keywords: Plant parasitic nematodes; Nematode-soil relationships; Coinertia analysis; Martinique; Dioscorea spp.; Lycopersicon esculentum

\section{Introduction}

Plant parasitic nematodes have biological characteristics that distinguish them from other organisms that affect the growth of plants, viz, they are rela-

\footnotetext{
* Corresponding author. ORSTOM, BP 1386 Dakar, Senegal. Tel.: +221-832-18-46; fax: +221-832-16-75; e-mail: patrice.cadet@orstom.sn.

${ }^{1}$ Tel.: +221-832-18-46; fax: +221-832-16-75; e-mail: jean.thioulouse@orstom.sn.
}

tively immobile and spend at least part of their life cycle within the soil matrix (Wallace, 1963). There, in the soil, they are dependent upon all events that happen in and on the field in which they live. As such, they are comparable to an agronomic factor, such as organic matter, and they can be managed in the same way, at the field scale (Greenland and Nye, 1959; Yeates, 1984). For example, fallowing can be used to increase the organic matter content of soil (Floret and Serpantié, 1993) and to reduce the number of nematodes (Ferris and Bernard, 1971; 
Netscher, 1985; Aung and Prot, 1990). Nematode abundance is highly dependent on the presence of the host plants. However, they are also influenced, to a greater or lesser extent, by most of the biological, chemical and physical components of the soil environment (Upadhyay et al., 1972; Jacq and Fortuner, 1979; Yeates, 1976, 1981; Cuc and Prot, 1992). As a result, there are soils or regions within soils that are unsuitable for particular nematode species and which, thus, contain fewer individuals or different nematode communities than more favourable environments. In the sugarcane fields in Martinique, when the lower soil horizons are brought to the surface, the balance between species in the community changes (Cadet and Albrecht, 1992). Generally, where low nematode numbers result from a biological cause, the soils are referred to as suppressive (Alabouvette, 1993; Stirling, 1991). Where they result from abiotic factors, the soils can be referred to as resistant (Amir and Alabouvette, 1993). For example, it is well known that Meloidogyne species are usually not abundant in clay soil (Kincaid, 1946). The term resistant soils could also include those in which crop damage is less than would be expected from the size of the nematode populations. Thus, for sugarcane, damage is less important in heavier soils than in sandy soils (Spaull and Cadet, 1990). This is not a result of fewer nematodes but rather a consequence of a slower rate of invasion of the roots by the nematodes, which allows sufficient time for the plant to develop its root system and, thus, to overcome subsequent injuries (Cadet et al., 1982).

It is well known that populations of plant parasitic nematodes can be controlled by growing resistant host plants. Nematode development can be prevented or limited by means of a genetic modification of the host (Berthou et al., 1989; Luc and Reversat, 1985). In a similar way, it seems possible that nematode populations could be controlled by modifying the abiotic components of their environment to create a resistant soil. So we can define mesological control as the reduction in size of the nematode populations, the change of the species balance in the communities and/or a reduction in the amount of root damage following the change in the abiotic environment (Cadet et al., 1994). For example, in South Africa and in West Africa, the same sugarcane varieties are cultivated on very similar sandy soils and they are parasitised by the same species. But the composition of the ectoparasitic communities is different (Cadet and Spaull, 1985). In South Africa, it is dominated by Xiphinema and trichodorids whereas in West Africa, it is dominated by Helicotylenchus. Despite the fact that the West African ectoparasite community is much larger than that of South Africa, the damage to ratoon crops occurs only in South Africa (Spaull and Cadet, 1990). If we could change the balance between species in the South African community by increasing the proportion of Helicotylenchus, we would expect the damage to disappear in ratoon crops.

The influence of various types of soil on the distribution of nematodes has been reported by many authors (Castro et al., 1990; Norton, 1979, 1989; Prot and van Gundy, 1979). The aim of the present study is to identify the physico-chemical factors which, independently from the type of soil, are correlated to the nematode communities which parasite tomato and yam crops in Martinique.

\section{Material and methods}

The survey was made in Martinique in the French West Indies. Seventy three tomato fields $\left(150 \mathrm{~m}^{2}\right.$ to $1.5 \mathrm{ha}$ ) were sampled between the fruit initiation stage and the first yield. Three to five subsamples were collected in each field, roughly along a transect. Each subsample comprised an entire tomato plant with its root system and soil from the rhizosphere. Roots were cut into about 1-mm lengths and the nematodes extracted from a $30-\mathrm{g}$ subsample in a mist chamber (Seinhorst, 1950). Each soil subsample was divided in two parts. The nematodes were extracted from each subsample by elutriation (Seinhorst, 1962). The level of infestation in the field was assumed to be equal to the average of the results obtained. For economical reasons, only one physico-chemical analysis was performed on a mixture of the subsamples to obtain the mean parameters of the field. The analyses performed on the soil samples were: Carbon (C), nitrogen $(\mathrm{N})$, organic matter (OM), $\mathrm{pH}$ (water: $\mathrm{pHO}$ and $\mathrm{KCl}: \mathrm{pHK})$, soil texture (clay: Cla; fine silt: FSi; coarse silt: CSi; fine sand: FSa; coarse sand: CSa), total phosphorus (P2O), exchange capacity $(\mathrm{CEC})$, calcium $(\mathrm{Ca})$, magnesium 
$(\mathrm{Mg})$, potassium $(\mathrm{K})$, sodium $(\mathrm{Na})$, saturation coefficient $(\mathrm{V} \%)$, wilting points $(2.5$ : WP2; 3.0: WP3; 4.2: WP4).

For yam (Dioscorea cayenensis-rotundata (CR) and D. alata (AL), totaling $94 \%$ of the yam fields), samples were taken after the emergence of the new tubers. As mixed plantations were very frequent, yams were sampled by variety, even if they were located on adjacent rows. Two varieties were selected. For each variety, three to five subsamples of soil from the rhizosphere, roots and new tuber skin (from the proximal area) were collected in the same bag. In the laboratory, nematodes were extracted separately from each of the root and tuber samples, but the soil samples coming from the same field were mixed before soil analysis.

Three nematode species were found in the roots and tubers of yam: Pratylenchus coffeae, Scutellonema bradys and, very infrequently, Meloidogyne sp. (Kermarrec et al., 1987; Jatala and Bridge, 1990). These nematodes first multiply in the roots before invading the new tuber (Bridge, 1982; Cadet and Quénéhervé, 1994). In other words, if a root system is infested, the new tuber will also become infested. For the data analysis, only the highest infestation density observed in the yam roots or in the new tuber of each plant has been used.
From these results, six data tables were built. Each row represents one tomato field or one yam field. Columns represent nematode species or soil parameters. Thus, the six tables are:

- nematological table for tomato fields: 73 rows and 17 columns,

- pedological table for tomato fields: 73 rows and 20 columns,

- nematological table for $D$. cayenensis-rotundata fields: 63 rows and 12 columns,

- pedological table for $D$. cayenensis-rotundata fields: 63 rows and 20 columns,

- nematological table for D. alata fields: 89 rows and 12 columns,

- pedological table for D. alata fields: 89 rows and 20 columns.

The abundance of nematode species or genera observed on these crops are listed in Table 1. The nematode numbers were transformed to $\log (x+1)$. These data sets were first studied separately with Principal Components Analysis (PCA) on correlation matrix. For pedological data, PCA on correlation matrix is well adapted because variables are expressed in different units. To analyse the nematological data, we could have used Correspondence Analysis (CA), but we have preferred to use a PCA after logarithm transformation because of the very high

Table 1

List of species and genera of plant parasitic nematodes found in yam and tomato crops in Martinique

\begin{tabular}{|c|c|c|c|c|c|c|}
\hline \multirow[t]{2}{*}{ Species } & \multicolumn{2}{|l|}{ Code } & \multicolumn{2}{|c|}{ Tomato } & \multicolumn{2}{|c|}{ Yam } \\
\hline & Soil & Root & Soil & Root & Soil & Root \\
\hline S. bradys & Scus & Scur & - & - & + & + \\
\hline P. coffeae & Pras & Prar & - & - & + & + \\
\hline Hoplolaimus seinhorsti & Hops & Hopr & + & + & - & - \\
\hline Aorolaimus luci & Aoro & & + & - & + & - \\
\hline Meloidogyne incognita and arenaria & Mels & Melr & + & + & + & + \\
\hline Criconemella ornata and onoensis & Cric & & + & - & + & - \\
\hline Helicotylenchus dihystera, erythrinae and retusus & Hels & Helr & + & + & + & - \\
\hline Rotylenchulus reniformis & Rots & Rotr & + & + & + & - \\
\hline Telotylenchus ventralis & Telo & & + & - & - & - \\
\hline Longidorus sp. & Long & & + & - & - & - \\
\hline
\end{tabular}

${ }^{\mathrm{a}}$ Not used in the calculations. 


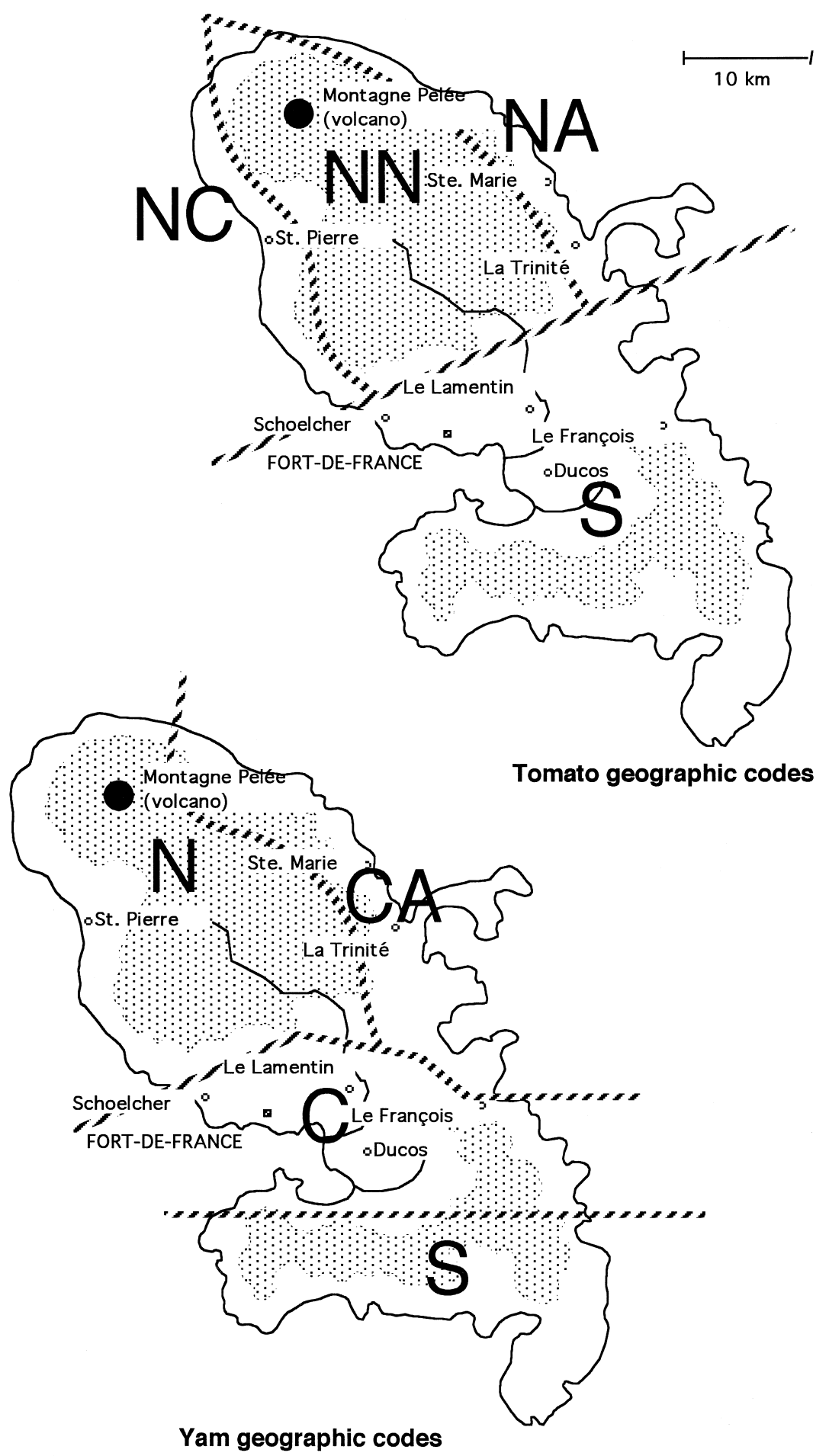

neer limits of areas 


\section{TOMATO}
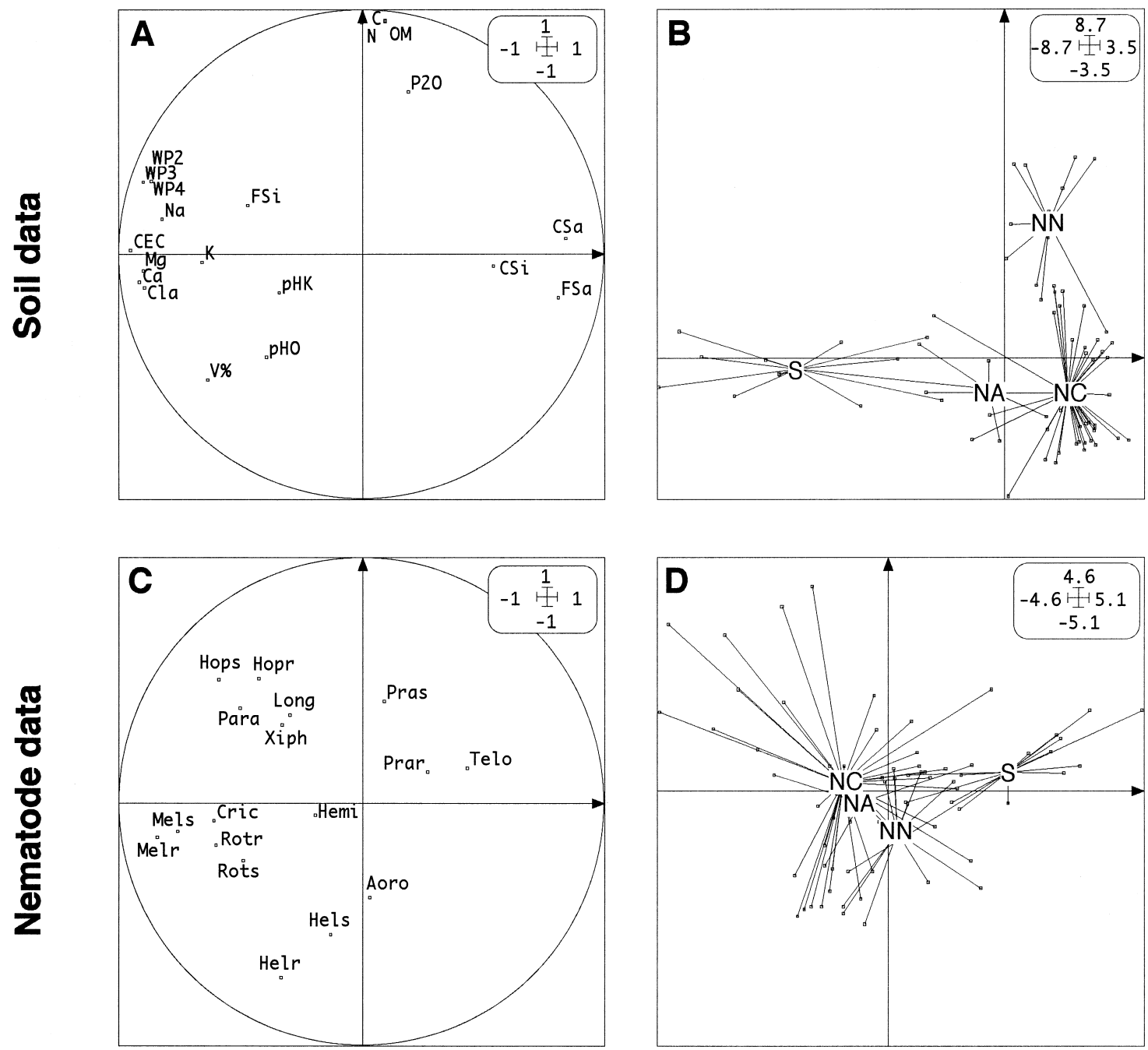

Fig. 2. Correlation circles and factor map $(\mathrm{F} 1 \times \mathrm{F} 2)$ of the PCA on pedological variables $(\mathrm{A}, \mathrm{B})$ and nematode species $(\mathrm{C}$, D) for tomato fields. Nematode species codes are given in Table 1, and pedological variable codes are given in the text (Section 2). On the factor maps, the fields are grouped according to the region to which they belong on the island (see Fig. 1). Each field is linked to the gravity centre of its region, and these gravity centres are labeled with region codes.

variability of the number of nematodes. This high variability causes stability problems in CA and PCA is, therefore, preferable. The fauna and the soil data were then coupled with coinertia analysis (Chessel and Mercier, 1993; Dolédec and Chessel, 1994). Computations and graphical displays were made with

Fig. 1. Geographical map of the Martinique showing tomato (above) and yam (below) crop zones defined on the island: (N) North; (NC) North Caribbean; (NN) North (Pelée Mountain); (NA) North Atlantic; (S) South; (CA) Centre Atlantic; (C) Centre. 
the ADE-4 software (Thioulouse et al., 1995, 1997) and GraphMu (Thioulouse, 1989). On the factor maps, fields are grouped according to their geographical locality on the island (Fig. 1).

Interpreting the results of coinertia analysis rests on the following mathematical property: the covariance between the principal axes in the nematological and pedological spaces is maximum. Two important steps must be considered.

The comparison between the PCA and coinertia analysis factor maps shows which species and which variables are of interest: the most interesting ones are the ones which positions are different in the PCA factor map and in the coinertia analysis factor map.

The comparison between the nematological and the pedological coinertia analysis factor maps shows which species are correlated with which variables: the species with high factor scores are correlated with variables having a high factor score on the same axis and in the same direction.

\section{Results}

\subsection{Nematological and soil characteristics of the tomato fields}

\subsubsection{Soil analysis}

The results of the analysis of the 20 soil variables collected from each field were subjected to the PCA. On the correlation circle built with the first two factors (67\% of the variability), the soil variables were distributed in three groups (Fig. 2A). One corresponding to proportions of sand (FSa and Csa) and coarse silt $(\mathrm{CSi})$, a second group with variables corresponding to the finer particles, clay ( $\mathrm{Cla}$ ) and fine silt (FSi), as well as cations, exchange capacity (CEC) and WP. The third group was characterised by organic matter and the phosphorus content.

Points corresponding to the different fields were projected in the first factor map and named according to their position on the island (Fig. 2B). Fields located in the south of the island $(\mathrm{S})$, whose vertisols have a high clay content are separated from those located in the north of the island (NC, NA, NN), whose andosols contained a high proportion of sand (pumice stones). In this cloud, two groups could be distinguished: one corresponding to fields situated on the Pelée Mountain sides (NN), and one corresponding to fields located on the atlantic (NA) or caribbean (NC) coasts. The soils of the Pelée Mountain sides are rich in carbon as a result of previous volcanic eruptions, whereas more distant soils have lower carbon content.

\subsubsection{Nematological analysis}

Tylenchorhynchus sp., which was only observed in one field, was removed from the fauna data before PCA. In the correlation circle, the different species were spread out in many groups (Fig. 2C). Telotylenchus (Telo) and Pratylenchus (Prar, Pras) were opposed to Meloidogyne (Melr, Mels) and Rotylenchulus (Rotr, Rots), both groups separated from Helicotylenchus (Hels, Helr) and Aorolaimus (Aoro). In the centre appeared Hemicriconemoides (Hemi).

In the factor map (Fig. 2D), fields located in the south (S) of Martinique were infested by Pratylenchus and Telotylenchus, but not with Meloidog$y n e$. Fields in the north of the island were generally infested by a more diverse community, including mainly Meloidogyne and Rotylenchulus. In this cloud, plots corresponding to fields located on the hillsides of the Pelée Mountain (NN) were grouped, because of large populations of Helicotylenchus and Aorolaimus. The fields located on the coast (NA and NC) contained Hoplolaimus and Xiphinema.

\subsection{Soil and nematological characteristics accord- ing to the cultivated yam variety}

\subsubsection{D. cayenensis-rotundata}

The simultaneous comparison of the correlation circle and factor map arising from the PCA of the soil data, showed that points corresponding to fields

\footnotetext{
Fig. 3. Correlation circles and factor maps $(\mathrm{F} 1 \times \mathrm{F} 2)$ of the PCA on pedological variables $(\mathrm{A}, \mathrm{B}, \mathrm{E}, \mathrm{F})$ and nematode species $(\mathrm{C}, \mathrm{D}, \mathrm{G}, \mathrm{H})$ for the two varieties of yam: D. cayenensis-rotundata (A, B, C, D) and D. alata (E, F, G, H). Nematode species codes are given in Table 1, and pedological variable codes are given in the text (Section 2). On the factor maps, the fields are grouped according to the region to which they belong on the island (see legend to Fig. 2).
} 

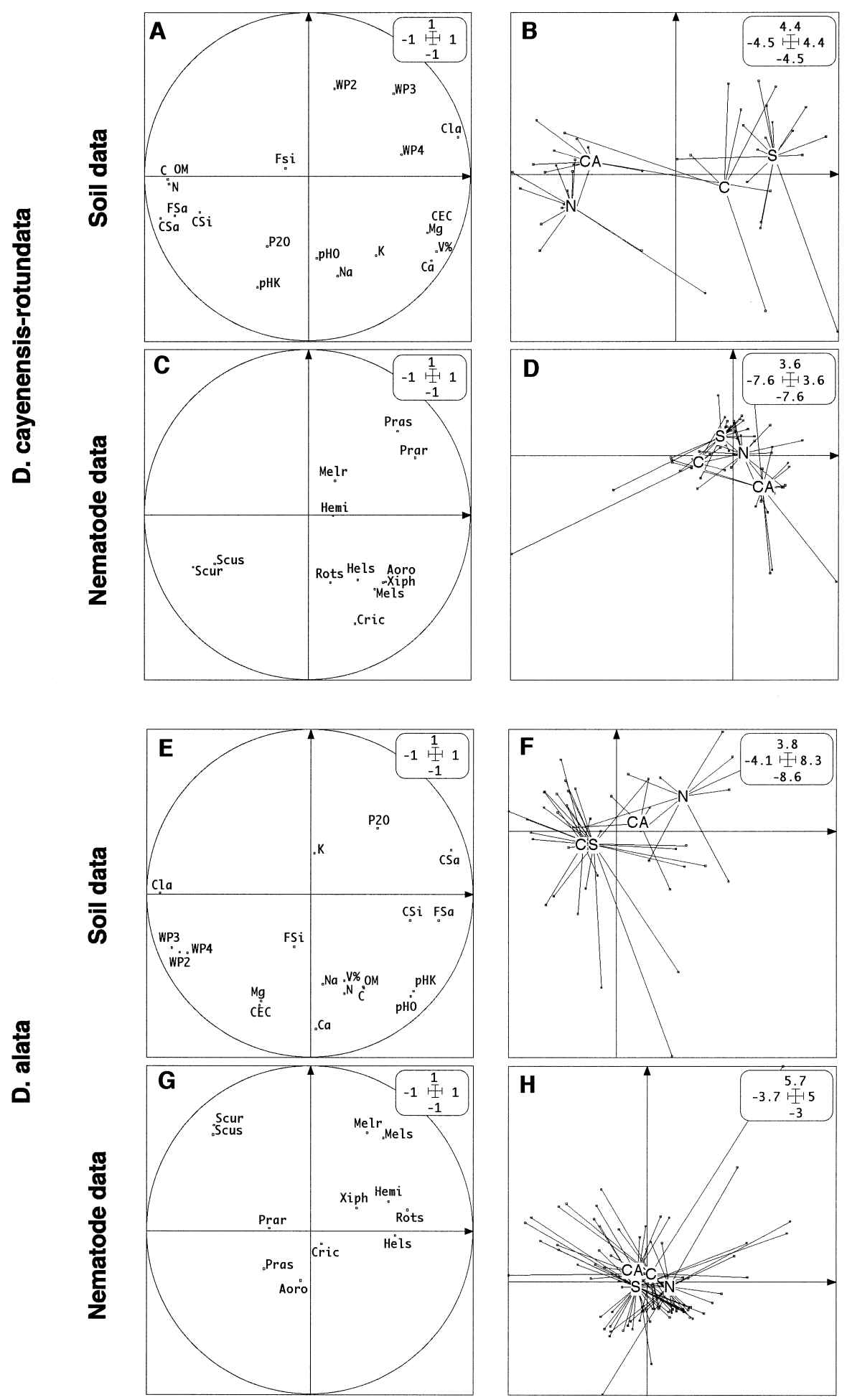
located in the centre (C) and the south (S) of the island, where the soil is more clayey, were opposed to fields located in the north and Atlantic centre (N and CA) because their soils are more sandy and rich in organic matter (Fig. 3A,B). On the nematological side, the factor map underlined the opposition between Scutellonema and Pratylenchus (Fig. 3C,D). A size effect appeared, because very few fields were infested by $S$. bradys. The points corresponding to fields infested with $P$. coffeae were grouped and a gradient of infestation in $P$. coffeae appeared from Atlantic centre (CA), to the south (S) where it was more abundant.

\subsubsection{D. alata}

A particle size gradient is shown by the soil data analysis. Points corresponding to clay fields in the south of the island are opposed to those corresponding to the few sandy pumice stone fields of the north (Fig. 3E,F), but the discrimination is not as sharp as for D. cayenensis-rotundata. Some fields in the south disturbed this repartition, due to the $\mathrm{pH}$. On the second factor, the separation of the fields depended on phosphorus, potassium content and on calcium content.

There was a little obvious structure in the factor map resulting from the analysis of the nematological data (Fig. 3G,H). Points corresponding to the location of the different fields were, for the most part, in the centre of the map. They did not show a strong relationship with their geographical position on the island (compared to D. cayenensis-rotundata), but rather with the decreasing abundance of $S$. bradys, from the first to the third quadrant, and with the presence of Meloidogyne.

\subsection{Nematode-soil relationships for tomato}

The coinertia analysis did not induce major changes (Table 2) but it showed the strong relationships between nematode numbers and soil characteristics (Fig. 4). It confirmed the link between the pumice stones andosol of the north of the island and the presence of Meloidogyne, whereas Pratylenchus and, in particular, Telotylenchus were associated with the fields on the slopes of the volcano, which were very rich in organic matter. Conversely, Helicotylenchus which occupied all types of soil was positioned in the centre of the factor map.

Coinertia analysis produced an approximate mirror image of the factor map (Fig. 4A). It still showed the particle size gradient (clay-sand), and a gradient of decreasing amount of organic matter.

The factor map derived from the nematological data (Fig. 4C) rotated around the horizontal axis, to reinforce some relationships: between Meloidogyne and the pumice andosol, between Aorolaimus and soils rich in organic matter, between Telotylenchus and the clay soils. Pratylenchus (P. brachyurus) and Helicotylenchus, which where not affected by soil type, were located in the middle of the map. All other species were more abundant in light soil. In addition, for Hoplolaimus or Longidorus, their $\mathrm{pH}$ tended to be higher (and the organic matter content lower) than for Criconemella and Rotylenchulus.

Both factor maps established from fauna and soil data were similar to those of the PCA. The Monte Carlo test was highly significant: the 10,000 row permutations provided no inertia value higher than that obtained with the original (non-permuted) data (Fig. 6A).

Table 2

Statistical characteristics of the coinertia analysis

\begin{tabular}{|c|c|c|c|c|c|}
\hline & & $\begin{array}{l}\text { Correlation F1 (N) vs. } \\
\text { F1 (S) }\end{array}$ & $\begin{array}{l}\text { Correlation F2 (N) vs. } \\
\text { F2 (S) }\end{array}$ & $\begin{array}{l}\text { Conserved } \\
\text { inertia }(\mathrm{N})\end{array}$ & $\begin{array}{l}\text { Conserved } \\
\text { inertia }(S)\end{array}$ \\
\hline \multirow[t]{2}{*}{ Tomato } & PCA & -0.71 & -0.47 & & \\
\hline & Coinertia & -0.78 & -0.79 & $99 \%$ & $89 \%$ \\
\hline \multirow[t]{2}{*}{ D. cayenensis-rotundata } & PCA & -0.44 & -0.026 & & \\
\hline & Coinertia & -0.78 & -0.52 & $97 \%$ & $82 \%$ \\
\hline \multirow[t]{2}{*}{ D. alata } & PCA & -0.142 & -0.04 & & \\
\hline & Coinertia & -0.61 & -0.54 & $57 \%$ & $70 \%$ \\
\hline
\end{tabular}

First two columns: correlation between nematode (N) and soil (S) factors (F1 and F2) for PCA and coinertia analysis.

Last two columns: percentages of the PCA inertia conserved by the coinertia analysis. Coinertia analysis steadily improves the correlation between nematode $(\mathrm{N})$ and soil $(\mathrm{S})$ factors, while keeping most of the inertia taken into account by PCA. 
TOMATO
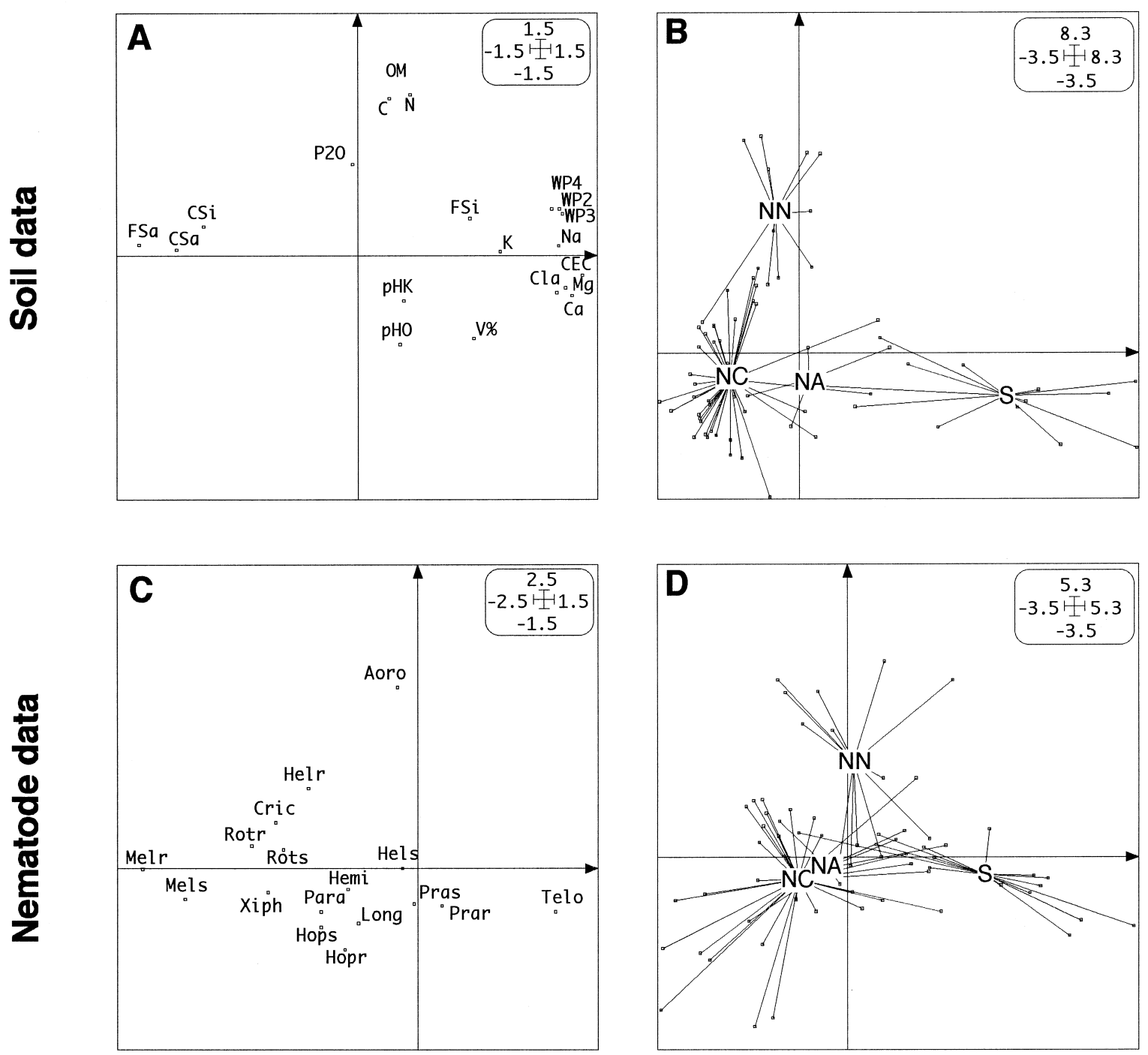

Fig. 4. Factor maps $(\mathrm{F} 1 \times \mathrm{F} 2)$ of the coinertia analysis on pedological variables $(\mathrm{A}, \mathrm{B})$ and nematode species $(\mathrm{C}, \mathrm{D})$ for tomato fields. Nematode species codes are given in Table 1, and pedological variable codes are given in the text (Section 2). On the factor maps, the fields are grouped according to the region to which they belong on the island (see legend to Fig. 2).

3.4. Nematode-soil relationships for the yam varieties

\subsubsection{D. cayenensis-rotundata}

The map rotated on the vertical axis. The coinertia analysis restored the particle size gradient (Fig. $5 \mathrm{~A})$ and the gradients for calcium, magnesium, phos- phorus and $\mathrm{pH}$. The importance of organic matter is underlined. The north $(\mathrm{N})$ and Atlantic centre (CA) samples contained a high proportion of organic matter and coarse particles, while the south (S) and centre samples (C) had a high proportion of clay particles (Fig. 5B).

There were few changes in the factor map derived from the nematode data (Fig. 5C). Aorolaimus 

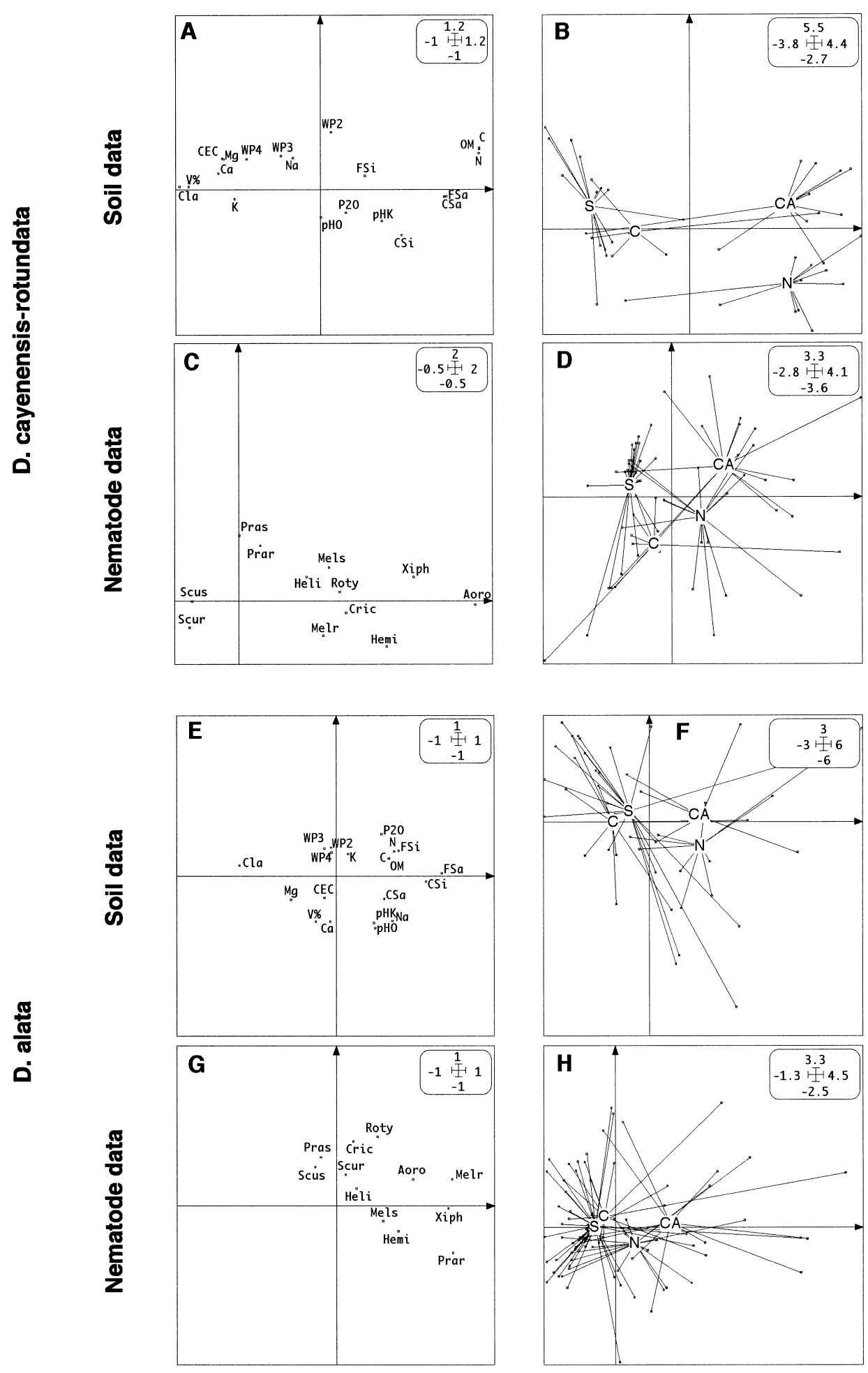

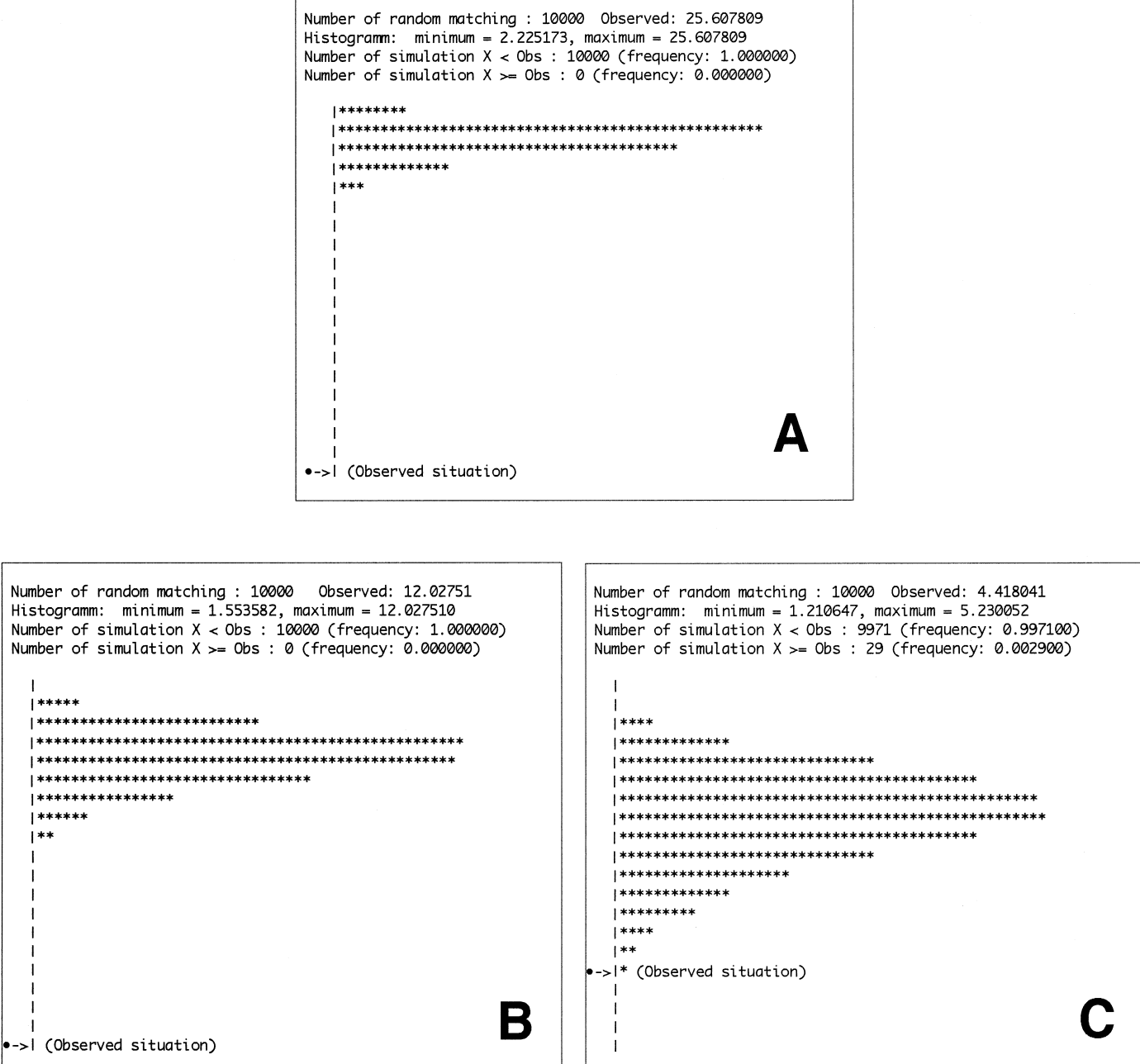

Fig. 6. Monte Carlo tests of the coinertia analysis for the tomato data (A), and each yam variety (B: D. cayenensis-rotundata, and C: D. alata). The observed situation point corresponds to the original coinertia analysis (with non-permuted rows). The value of the inertia for this situation is given in the first row. The histograms show the distribution of the criterion (total inertia) for the 10,000 analyses with randomly permuted rows.

moved on the map according to its association with andosol rich in organic matter. For $P$. coffeae, its presence in the soil was linked to a relatively higher exchange capacity, high rate of magnesium and calcium (Table 3 ) and lower $\mathrm{pH}$. The relative positions of geographical regions obtained in the pedological analysis is conserved in the nematological analysis (Fig. 5D).

The Monte Carlo test was highly significant ( $p<$ $10^{-5}$, Fig. 6B).

Fig. 5. Factor maps $(\mathrm{F} 1 \times \mathrm{F} 2)$ of the coinertia analysis on pedological variables $(\mathrm{A}, \mathrm{B}, \mathrm{E}, \mathrm{F})$ and nematode species $(\mathrm{C}, \mathrm{D}, \mathrm{G}, \mathrm{H})$ for the two varieties of yam: D. cayenensis-rotundata $(\mathrm{A}, \mathrm{B}, \mathrm{C}, \mathrm{D})$ and D. alata $(\mathrm{E}, \mathrm{F}, \mathrm{G}, \mathrm{H})$. Nematode species codes are given in Table 1 , and pedological variable codes are given in the text (Section 2). On the factor maps, the fields are grouped according to the region to which they belong on the island (see legend to Fig. 2). 
Table 3

Average exchangeable calcium and magnesium (meq\%) in the sample with low $(-)$ and high $(+)$ population of $P$. coffeae, for D. alata and D. cayenensis-rotundata

\begin{tabular}{lllll}
\hline & \multicolumn{2}{l}{ D. alata } & \multicolumn{2}{c}{$\begin{array}{l}\text { D. cayenensis- } \\
\text { rotundata }\end{array}$} \\
\cline { 2 - 5 } P. coffeae & - & + & + & - \\
\hline $\mathrm{Ca}$ & 5.7 & 5.6 & 4.9 & 4 \\
$\mathrm{Mg}$ & 2.9 & 2.6 & 2.3 & 1.8 \\
\hline
\end{tabular}

\subsubsection{D. alata}

The factor map obtained after coinertia analysis of the soil variables described the soil particle size gradient, but by taking the finer particles (clay and fine sand) into account (Fig. 5E). There was a notable change in the position of two groups of variables, viz, the wilting point values, the importance of which decreased by slipping closer to the origin, and organic matter, which migrated to underline the relationship with Aorolaimus.

Almost all nematode species occupied different positions on the factor map were resulting from the coinertia analysis (Fig. 5G). S. bradys in roots was no longer a deciding factor and moved close to the centre of the map, far from $P$. coffeae in the field soils with low $\mathrm{pH}$, high sodium content and poor in calcium and magnesium (Table 3 ).

There did not appear to be any obvious structures on the factor maps derived from the coinertia analysis of the nematological data or the soil data, except the opposition between the heavy soil of the south of the island and the lighter pumice stone soil of the north (Fig. 5F,H).

The Monte Carlo test by row permutation showed a spread out histogram (Fig. 6C). Among 10,000 permutations, $29(0.29 \%)$ gave a result identical or superior to that obtained with the original (non-permuted) data set. This result, although still highly significant, is very different from the one obtained for D. cayenensis-rotundata (Fig. 6B).

\section{Discussion}

In Martinique, tomato and yam are often cultivated in the same areas, but generally, tomato fields are more numerous in the north, whereas yam fields are more frequent in the south. Both crops are linked to the soil particle size gradient. This structure was maintained after coinertia analysis, but is less strong for D. alata. The study of the yam fields was characterised by an opposition between two nematode species: P. coffeae and S. bradys. This opposition derived from the different host-parasite relationships of the two most cultivated yam varieties: D. cayenensis-rotundata was attacked almost exclusively by $P$. coffeae and $D$. alata, was attacked in addition by $S$. bradys (Castagnone Sereno and Kermarrec, 1988).

These results add to those of others (Wallace, 1969; Cadet and Albrecht, 1992; Prot and van Gundy, 1981) that show soil texture plays an important role in explaining the relationships between soil and nematode species. In our study, these relationships appeared best in the parasitic nematode community of tomato, because the planting out of plants grown in a nursery avoided the introduction of nematodes with the planting material. The plants were attacked only by a nematode community already existing in the soil of the field. Obviously, if these nematodes were present in the soil, environmental conditions must have been favourable for their survival. For the tomato crop, most of the nematode species, such as Meloidogyne, preferred soils with coarse particles. Whereas for endoparasitic rootknot nematodes, the relationship appeared strictly dependant on soil particle size, for ectoparasitic species, chemical factors ( $\mathrm{pH}$, phosphorus) and, for Aorolaimus, organic matter may have a secondary influence on their abundance. P. brachyurus was present in all types of soil and thus did not appear to be influenced by the soil physico-chemical characteristics.

For yam, the nematode-soil relationships were the same as for the tomato and were issued mainly from the affinity of ectoparasitic species (or of Meloidogyne) for the light andosols, or from the affinity of Aorolaimus for the same soil but rich in organic matter. For D. cayenensis-rotundata, the species $P$. coffeae did not seem strongly linked to a specific soil texture, but appeared to be influenced secondarily by some soil chemical characteristics, such as calcium and magnesium or $\mathrm{pH}$. This result can be explained because this species, even though it was often brought to the field in the yam seed tuber, 
is found naturally in the field as an endemic species (Kermarrec et al., 1987). It can develop on other plants, such as, for example, banana, which is frequently grown in rotation with yam (Fargette and Quénéhervé, 1988; Fournet et al., 1990; Quénéhervé et al., 1995).

For D. alata, the nematode-soil relationship also exists because this variety is parasitised by the same nematode species as $D$. cayenensis-rotundata. But the relationship is weaker (as shown by coinertia analysis permutation test, Fig. 6C) because $D$. alata is also parasitised by $S$. bradys. As revealed by coinertia analysis, this species is not dependent from soil factors (shift toward the centre of the factor map, Fig. 5G). This situation can be explained by the origin of the infestation by $S$. bradys. This exotic species, which was introduced into Martinique in the 1970's, with the D. alata variety, was brought into the field within the seed tubers (Jatala and Bridge, 1990). It does not survive in the soil after the yam crop is harvested. In addition, $S$. bradys and $P$. coffeae rarely cohabit in the same tuber (Castagnone Sereno and Kermarrec, 1988), with the result that the corresponding variable ( $P$. coffeae in the roots) was thrown in the opposite position on the coinertia factor map. The $P$. coffeae-soil relationships were expressed from its abundance in soil (variable $P$. coffeae in the soil). We found, in particular, an influence of $\mathrm{pH}$, and sodium, calcium and magnesium content. The results obtained are not inconsistent because as the two varieties were not cultivated in exactly the same area, the lowest content of one element for $D$. alata was higher to the highest content of the same element for $D$. cayenensis rotundata.

The behaviour of $S$. bradys explains why the nematode-soil relationships for D. alata, were weak, as shown by the row permutation test. For $D$. cayenensis-rotundata, or for the tomato, the test was very highly significant. In these cases, nematode-soil relationships were very strong because all parasitizing nematodes carried out a part of their life in the soil. The validity of the results was reinforced by the fact that the same relationships were emphasised for the yam and the tomato surveys.

Twenty five years after $S$. bradys was introduced into Martinique, it is surprising that its cohabitation with $P$. coffeae in the tubers of $D$. alata was not more frequent, as $P$. coffeae occurs naturally in the soil. To explain this phenomenon, we hypothesise that the presence of $P$. coffeae in the soil before planting gives a deciding advantage to this species. From the soil, it has the opportunity to invade the yam roots before $S$. bradys, which was found only in the seed tuber where it had first to multiply before migrating to the roots. Therefore, the roots constituted an intermediate centre of multiplication, which allowed the nematodes to "wait" for the emergence of the new tuber (Bridge, 1982; Cadet and Quénéhervé, 1994). If these roots are already occupied by $P$. coffeae, it is possible that $S$. bradys is unable to compete and to multiply. Thus, the new tubers are usually only infested by $P$. coffeae. On this basis, $S$. bradys could eventually disappear from Martinique. In addition, the reverse situation does not exist, that is to say $P$. coffeae in yam plants was never in competition with $S$. bradys which was not found in the soil, except for the females that leave the infested tuber after planting. However, the economic problem would not be resolved with the disappearance of $S$. bradys because $P$. coffeae causes equivalent damage (Acosta and Ayala, 1976).

The study revealed that the abundance of $P$. coffeae was linked to particular soil chemical characteristics such as $\mathrm{pH}$, and sodium, calcium or magnesium content. The manipulation of these environmental abiotic factors is technically possible and could reduce the multiplication of $P$. coffeae during the period the yams are in the soil and thus reduce the damage caused after harvest during the storage period (Adesiyan et al., 1975; Cadet and Daly, 1996). This method of control can, however, only be considered for nematode species which are susceptible to chemical factors.

When soil texture is involved, cultural control methods could be developed. For example, the addition of organic matter to light textured soils infested with Meloidogyne is known to considerably decrease the damage caused by these parasites (Akhtar and Alam, 1993; Goswami and Meshram, 1991). Several hypothesis could explain this phenomenon, such as organic acid toxicity, development of predatory fungi and bacteria, antagonistic organisms. However, from our results the modification of the soil texture by the organic matter could be the principal factor. 


\section{Conclusion}

It is worth to notice that in this study, the coinertia analysis permutation tests reveal the peculiarity of nematode parasitism by showing a weaker relationship between an exotic nematode species and the soil variables. This method is a useful mathematical technique to identify relationships between the presence of some nematode species and physico-chemical characteristics of the soil. Manipulating certain chemical elements present in very low proportions in the soil, for example by the addition of chemical fertilizer, could influence nematode community by creating an unfavourable soil environment, without destroying the overall balance of the ecosystem.

\section{Acknowledgements}

The authors thank B. Hostachy, J.N. Mutz and A. Desprats who collected the samples, Dr. V.W. Spaull and the two anonymous referees for their useful comments and help in English translation.

\section{References}

Acosta, N., Ayala, A., 1976. Effect of Pratylenchus coffeae and Scutellonema bradys alone and in combination on Guinea yam (Dioscorea rotundata). J. Nematol. 8, 315-317.

Adesiyan, S.O., Odihirin, R.A., Adeniji, M.O., 1975. Economic losses caused by the yam nematode, Scutellonema bradys, in Nigeria. Plant Dis. Rep. 59, 477-480.

Akhtar, M., Alam, M.M., 1993. Utilization of waste materials in nematode control: a review. Bioresour. Technol. 45, 1-7.

Alabouvette, C., 1993. Naturally occurring disease-suppressive soils. Pest management: biologically based technologies. In: Lumsden, R.D., Vaughn, J.L. (Eds.), Conference Proceedings Series. ACS Books, Washington, pp. 204-210.

Amir, H., Alabouvette, C., 1993. Involvement of soil abiotic factors in the mechanisms of soil suppressiveness to fusarium wilts. Soil Biol. Biochem. 25, 157-164.

Aung, T., Prot, J.C., 1990. Effects of crop rotations on Pratylenchus zeae and yield of rice cultivar UPL Ri-5. Revue de Nématologie 13, 445-448.

Berthou, F., Ba-Diallo, A., de Mayer, L., de Guiran, G., 1989. Caractérisation chez les nématodes Meloidogyne goeldi (Tylenchida) de types virulents vis à vis du gène $\mathrm{Mi}$ de la tomate dans deux zones maraîchères au Sénégal. Agronomie 9, 877-885.
Bridge, J., 1982. Nematodes of yams. In: Miege, J., Lyonga, S.N. (Eds.), Yams. Clarendon Press, Oxford, pp. 253-264.

Cadet, P., Albrecht, A., 1992. Le remodelage des terres à la Martinique: 3. Effet sur le peuplement de nématodes parasites de la canne à sucre en relation avec la croissance végétale. Cahiers de 1'ORSTOM, Série Pédologie 27, 49-58.

Cadet, P., Daly, P., 1996. Use of nematicides to produce yam planting material free of Scutellonema bradys in Martinique (French West Indies). Crop Protection 15 (2), 187-195.

Cadet, P., Quénéhervé, P., 1994. Fluctuations naturelles de Scutellonema bradys (Nematoda: Hololaimidae) au cours de la croissance et du stockage de l'igname (Dioscorea alata) à la Martinique. Nematologica 40, 587-600.

Cadet, P., Spaull, V.W., 1985. Studies on relationship between nematodes and sugarcane in South and West Africa: plant cane. Revue de Nématologie 8, 131-142.

Cadet, P., Quénéhervé, P., Merny, G., 1982. Pathogenic action of nematodes on irrigated sugarcane. Revue de Nématologie 5 , 205-209.

Cadet, P., Thioulouse, J., Albrecht, A., 1994. Relationships between ferrisol properties and the structure of plant parasitic nematode communities on sugarcane in Martinique (French West Indies). Acta Ecol. 15, 767-780.

Castagnone Sereno, P., Kermarrec, A., 1988. Association between Pratylenchus coffeae and Scutellonema bradys in yam tubers under agronomic conditions in the French West Indies. Nematropica $18,155-157$.

Castro, C.E., Belser, N.O., Mckinney, H.E., Thomason, I.J., 1990. Strong repellency of the root knot nematode, Meloidogyne incognita by specific inorganic ions. J. Chem. Ecol. 16, 11991205.

Chessel, D., Mercier, P., 1993. Couplage de triplets statistiques et liaison espéce-environnement. In: Lebreton, J.D., Asselain, D. (Eds.), Biométrie et Environnement. Masson, Paris, pp. 15-44.

Cuc, N.T.T., Prot, J.C., 1992. Effect of changing the agricultural environment on ufra occurrence in the Mekong delta. Intern. Rice Res. Newslett. 17, 25.

Dolédec, S., Chessel, D., 1994. Co-inertia analysis: an alternative method for studying species-environment relationships. Freshwater Biol. 31, 277-294.

Fargette, M., Quénéhervé, P., 1988. Populations of nematodes in soils under banana, cv Poyo, in the Ivory Coast: 1. The nematofauna occurring in the banana producing areas. Revue de Nématologie 11, 239-244.

Ferris, V.R., Bernard, R.L., 1971. Crop rotation effects on population densities of ectoparasitic nematodes. J. Nematol. 3, 119122

Floret, C., Serpantié, G., 1993. La jachère en Afrique de l'Ouest. ORSTOM, Colloques et séminaires, Paris.

Fournet, J., Kermarrec, A., Dos Santos, F., 1990. Poblaciones de malezas y nematodos hospedados por algunas de ellas en los cultivos de name de la Basse Terre (Guadalupe). Turrialba 40, 257-264.

Goswami, B.K., Meshram, N.J., 1991. Studies on comparative efficacy of mustard and karanj oil seed cakes with nematicide, carbofuran against root-knot nematode, Meloidogyne incognita on tomato. Indian J. Nematol. 21, 66-70. 
Greenland, D.J., Nye, P.H., 1959. Increases in the carbon and nitrogen contents of tropical soils under natural fallows. J. Soil Sci. 10, 284-299.

Jacq, V., Fortuner, R., 1979. Biological control of rice nematodes using sulphate reducing bacteria. Revue de Nématologie 2, 41-50.

Jatala, P., Bridge, J., 1990. Nematode Parasites of Root and Tuber Crops. In: Luc, M., Sikora, A., Bridge, J. (Eds.), Plant Parasitic Nematodes in Subtropical and Tropical Agriculture. C.A.B. International, Wallingford, pp. 137-180.

Kermarrec, A., Castagnone-Sereno, P., Degras, L., Anais, A., Denon, D., 1987. Nouvelle distribution de Scutellonema bradys (Tylenchida, Hoplolaiminae) dans la Caraïbe: le cas des Antilles Françaises. Mededelingen Faculteit Landbouwwetenschappen Gent 52, 617-624.

Kincaid, R.R., 1946. Soil factors affecting incidence of root knot. Soil Sci. 61, 101-109.

Luc, M., Reversat, G., 1985. Possibilités et limites des solutions génétiques aux affections provoquées par les nématodes sur les cultures tropicales. Comptes Rendus des Séances de l'Académie d'Agriculture Française 71, 781-791.

Netscher, C., 1985. A crop rotation to control root-knot nematodes in the tropics. Int. Nematol. Network Newslett. 2, 14-15.

Norton, D.C., 1979. Relationship of physical and chemical factors to populations of plant-parasitic nematodes. Annu. Rev. Phytopathol. 17, 279-299.

Norton, D.C., 1989. Abiotic soil factors and plant-parasitic nematode communities. J. Nematol. 21, 299-307.

Prot, J.C., van Gundy, S.D., 1979. Influence of soil type and temperature on the migration of Meloidogyne incognita juveniles toward tomato roots. Nematropica 9, 104-105.

Prot, J.C., van Gundy, S.D., 1981. Effect of soil texture and the clay component on migration of Meloidogyne incognita second-stage juveniles. J. Nematol. 13, 213-217.

Quénéhervé, P., Drob, F., Topart, P., 1995. Host status of some weeds to Meloidogyne spp., Pratylenchus spp., Helicotylenchus spp. and Rotylenchulus reniformis associated with vegetables cultivated in polytunnels in Martinique. Nematropica $25,149-157$.
Seinhorst, J.W., 1950. De betekenis van de toestand van de grond voor het optreden van aantasting door het stengelaaltje ( $\mathrm{Di}$ tylenchus dipsaci (Kühn) Filipjev). Tijdschrift over Plantenziekten 56, 289-349.

Seinhorst, J.W., 1962. Modification of the elutriation method for extracting nematodes from soil. Nematologica 8, 117-128.

Spaull, V.W., Cadet, P., 1990. Nematode parasites of sugarcane. In: Luc, M., Sikora, A., Bridge, J. (Eds.), Plant Parasitic Nematodes in Subtropical and Tropical Agriculture. CAB International, Wallingford, pp. 461-491.

Stirling, G.R., 1991. Biological control of Plant Parasitic Nematodes. CAB International, Wallingford.

Thioulouse, J., 1989. Statistical analysis and graphical display of multivariate data on the Macintosh. Comput. Appl. Biosci. 5, 287-292.

Thioulouse J., Dolédec S., Chessel D., Olivier J.M., 1995. ADE software: multivariate analysis and graphical display of environmental data. In: Guariso, G., Rizzoli, A. (Eds.), Software per l'ambiente. Pàtron editore, Bologne, pp. 57-62.

Thioulouse, J., Chessel, D., Dolédec, S., Olivier, J.M., 1997. ADE-4: a multivariate analysis and graphical display software Stat. Comput. 7 (1), 75-83.

Upadhyay, R.S., Oostenbrink, M., Khan, A.M., 1972. The effect of different soil type on the density of nematode populations. Indian J. Nematol. 2, 42-53.

Wallace, H.R., 1963. The Biology of Plant Parasitic Nematodes. Edward Arnold Publishers, London.

Wallace, H.R., 1969. The influence of nematode numbers and of soil particle size, nutrients and temperature on the reproduction of Meloidogyne javanica. Nematologica 15, 55-64.

Yeates, G.W., 1976. Effect of fertiliser treatment and stocking rate on pasture nematode populations in a yellow-grey earth. New Zealand J. Agric. Res. 19, 405-408.

Yeates, G.W., 1981. Soil nematode populations depressed in the presence of earthworms. Pedobiologia 22, 191-195.

Yeates, G.W., 1984. Variation in soil nematode diversity under pasture with soil and year. Soil Biol. Biochem. 16, 95-102. 